\title{
Pelatihan kewirausahaan: Pengolahan sampah plastik menjadi produk bernilai jual bagi ibu-ibu rumah tangga dan remaja
}

\author{
Muhammad Rakib ${ }^{1}$, Ilham Thaief ${ }^{2}$, Dian Anugrah Sanusi ${ }^{3}$ \\ ${ }^{1,2}$ Universitas Negeri Makassar \\ ${ }^{3}$ Universitas Satya Wiyata Mandala
}

\begin{abstract}
The partner of this Community Partnership Program (PKM) was Labakkang District Head, Pangkep Regency. The problem is: (1) the lack of public knowledge (housewives and young women) about the use of plastic waste into selling value products and (2) the lack of skills of housewives and young women in processing plastic waste into sale value products. The targets are housewives and young women. The methods used are: observation, testing, training, and evaluation. The results achieved are (1) housewives and young women have very high levels of participation in training in processing plastic waste into valuable products and (2) housewives and young women have the knowledge and skills to process plastic waste into products selling value.
\end{abstract}

Keywords: entrepreneurship training, plastic waste, selling products

\section{PENDAHULUAN}

Program Kemitraan Masyarakat (PKM) yang telah dilaksanakan bermitra dengan Camat Labakkang Kabupaten Pangkep. Jumlah kepala rumah tangga di Kecamatan Labakkang yaitu 10.026 KK dan jumlah Penduduk sebanyak 46.440 jiwa meliputi 21.881 laki-laki dan 24.559 perempuan. Pada umumnya penduduk perempuan bekerja sebagai ibu rumah tangga murni tanpa memiliki pekerjaan/usaha yang dapat membantu pendapatan rumah tangganya. Berdasarkan hasil wawancara dan pengamatan, Ibu-ibu rumah tangga dan putri memiliki banyak waktu luang yang dapat dimanfaatkan untuk melakukan kegitan ekonomi untuk membantu pendapatan keluarganya.

Permasalahan ibu-ibu rumah tangga dan remaja putri di Kecamatan Labakkang adalah tingkat partisipasinya masih rendah dalam setiap pelaksanaan program pemerintah yang berkaitan dengan pemberdayaan masyarakat. Selain itu, juga kurangnya keterampilan yang dimiliki untuk dijadikan sebagai modal dalam melakukan kegiatan produktif untuk menambah pendapatan rumah tangganya. Kondisi tersebut, masih dipengaruhi oleh anggapan masyarakat pada umumnya bahwa perempuan harus tinggal di rumah mengurusi keluarga sedangkan laki-laki memiliki tanggung jawab mencari nafkah untuk keluarganya. Sebagaimana dikemukakan oleh White \& Hastuti dalam Djabu et al. (2013) bahwa sistem kebudayaan patrilineal menjadi penyebab rendahnya partisipasi perempuan dalam aktivitas ekonomi. Dalam sistem patrilineal, peran istri dianggap lebih rendah daripada pria, sehingga dominasi pria semakin kuat dalam aktivtas perekonomian. Meskipun demikian, tidak sedikit pula istri yang memilih bekerja untuk meningkatkan kesejahteraan keluarga.

Kesejahteraan keluarga dapat terwujud dengan adanya sistem manajemen yang baik, serta berjalannya fungsi dan perang masing-masing anggota keluarga (Marzuki, 2015). Hal ini menunjukkan bahwa antara peran suami sebagai kepala rumah tangga dan istri sebagai ibu rumah tangga harus berjalan dengan seiring sejalan. Suami sebagai kepala keluarga bertanggung jawab untuk mencari nafkah demi kesejahteraan keluarga. Di sisi lain sebagai ibu rumah tangga, istri harus mempunyai kreativitas dalam mengelola ekonomi keluarga.

Penelitian mengenai upaya-upaya ibu rumah tangga dalam membangun kesejahteraan keluarga sudah banyak dilakukan Anwar (2013) mengungkapkan bahwa organisasi perempuan di desadesa merupakan wujud kreativitas istri dalam meningkatkan kesejahteraan keluarga. Gerakan feminisme melalui institusi merupakan salah satu 
wujud upaya perempuan dalam memerangi kemiskinan dan memajukan kesejahteraan keluarga, ketika pendapatan suami kurang atau bahkan tidak mendapat nafkah ekonomi dari suami.

Selain itu, Marzuki (2015) juga melakukan penelitian mengenai peran lembaga pemberdayaan masyarakat dalam meningkatkan pendapatan ibu rumah tangga. Hasil penelitian menunjukkan bahwa lembaga pemberdayaan masyarakat mampu berperan signifikan dalam meningkatkan pendapatan keluarga. Peran lembaga pemberdayaan masyarakat sangat dirasakan oleh ibu rumah tangga yang menjadi single parent, dan juga ibu rumah tangga dengan keadaan eknomi lemah, karena penghasilan petani yang sangat bergantung pada kondisi alam.

Attamimi (2012) juga melakukan penelitian mengenai istri yang bekerja dalam perspektif Islam. Hasil penelitian menunjukkan bahwa terdapat beberapa faktor yang mendorong istri memiliki peran ganda, salah satunya adalah keterpaksaan karena keadaan ekonomi yang lemah. Agama Islam juga mendukung adanya kesetaraan gender, artinya perempuan juga berhak untuk mengembangkan kemampuan dan potensi yang ada dalam dirinya.

Penelitian mengenai ibu rumah tangga yang memiliki peran ganda juga dilakukan oleh Afrina \& Nurhamlin (2014). Hasil penelitian menunjukkan bahwa ibu rumah tangga yang memiliki peran ganda disebabkan karena himpitan ekonomi seperti tanggungan keluarga yang banyak dan besarnya biaya pendidikan anak. Ibu rumah tangga yang bekerja justru memiliki latar belakang pendidikan SMA ke atas. Hasil penelitian juga menunjukkan bahwa meskipun berperan ganda ibu rumah tangga juga mampu menjalankan fungsi keluarga dengan baik. Dari penelitian-penelitian sebelumnya terungkap fakta bahwa upaya untuk mensejahterakan keluarga tidak hanya menjadi tanggungjawab kepala keluarga, tetapi juga dilakukan oleh ibu rumah tangga. Penelitian ini akan mengelaborasi upaya-upaya ibu rumah tangga dalam membangun kesejahteraan keluarga. Pelatihan ini difokuskan untuk ibu-ibu rumah tangga dan remaja putri tidak bekerja.

\section{METODE PELAKSANAAN}

Mitra dalam pelaksanaan program ini adalah camat Labakkang. Dalam pelaksanaan pengabdian ini mitra menyiapkan peserta pelatihan dari ibu-ibu rumah tangga dan remaja putri yang belum bekerja sebanyak 39 orang yang merupakan perwakilan dari 13 desa/kelurahan di Kecamatan Labakkang Kabupaten Pangkep. Jumlah peserta tersebut ditetapkan secara proporsional yaitu setiap desa/ kelurahan diwakili oleh 3 orang. Metode yang digunakan dalam penerapan IPTEKS ini adalah ceramah, diskusi dan praktek. Prosedur pelaksanaan penerapan IPTEKS ini adalah observasi, testing, pelatihan, dan evaluasi.

\section{HASIL DAN PEMBAHASAN}

Prosedur pelaksanaan pelatihan adalah observasi, testing, pelatihan, dan evaluasi. Secara rinci, uraian teknik pelaksanaan dan tujuan dari masingmasing tahapan diuraikan sebagai berikut.

\section{A. Tahap Observasi}

Observasi dilakukan sebelum pelatihan dilaksanakan yaitu diperoleh informasi bahwa tingkat pendidikan yang dimiliki oleh peserta pelatihan sebagian besar sekolah menengah atas, usia antara 17-50 tahun, aktivitas sehari-hari sebagai ibu rumah tangga sehingga mereka memiliki waktu lowong setiap sore antara jam 15.30-17.00 Wita. Dengan demikian pelatihan dilaksanakan sesuai dengan waktu lowong peserta agar pelatihan yang dilakukan tidak mengganggu aktivitasnya sebagai ibu rumah tangga.

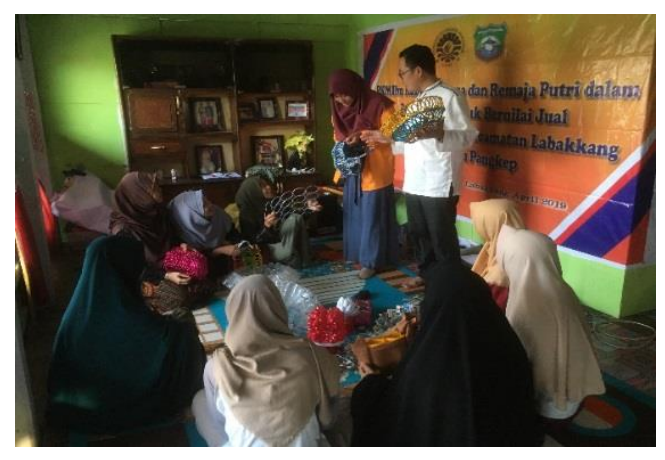

Gambar 1. Tim pengabdi dan instruktur (mahasiswa) memberikan penjelasan teknis 


\section{B. Tahap Testing}

Tahap ini dilakukan untuk mengetahui kemampuan dasar ibu rumah tangga dan remaja putri mengenai pemanfaatan sampah plastik. Hasil testing menunjukkan bahwa pada umumnya peserta pelatihan belum memiliki pengetahuan dan keterampilan mengenai pengolahan limbah plastik menjadi produk bernilai jual. Hal tersebut dijadikan bahan pertimbangan dalam merencanakan materi yang akan dilatihkan kepada mereka. Adapun materi pelatihan sesuai dengan kebutuhan peserta adalah pengetahuan tentang sampah plastik dan permasalahannya, pemanfaatan sampah plastik dalam berbagai produk.

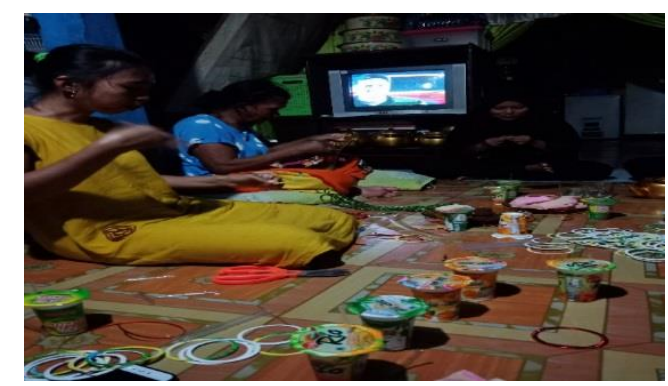

Gambar 2. Kelompok Kanaungan membuat keranjang dari gelas plastik

\section{Tahap Pelatihan}

Pada tahap ini dilakukan pelatihan berdasarkan hasil dari observasi dan testing. Pelatihan dilaksanakan dalam dua sesion yakni sesion teoretik dan sesion praktikum. Pada sesion teoretik dilakukan kegiatan berupa penyampaian materi tentang sampah pastik dan permasalahannya. Pada sesi praktikum dilakukan kegiatan berupa pembimbingan membuat berbagai produk bernilai jual dan dapat dijadikan sebagai sumber pendapatan keluarga seperti keranjang, tempat tissue, toples, tempat air gelas, pas bunga, dan lain-lain.

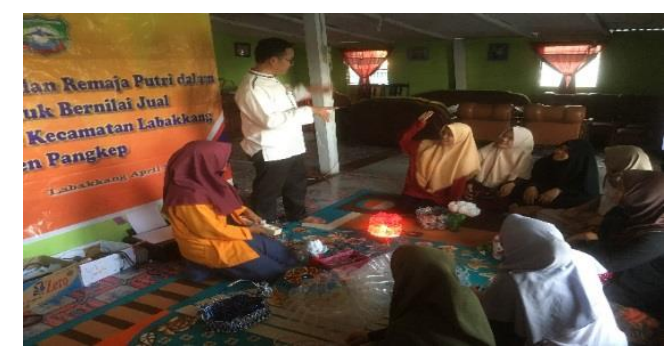

Gambar 3. Tanya jawab dengan peserta pelatihan

\section{Tahap Evaluasi}

Pada tahap ini dilakukan kegiatan evaluasi untuk mengukur sejauh mana keberhasilan pelatihan yang telah dilakukan. Evaluasi yang dilakukan yaitu melihat tingkat partisipasi peserta dalam proses pelatihan dan tingkat keterampilan membuat produk.

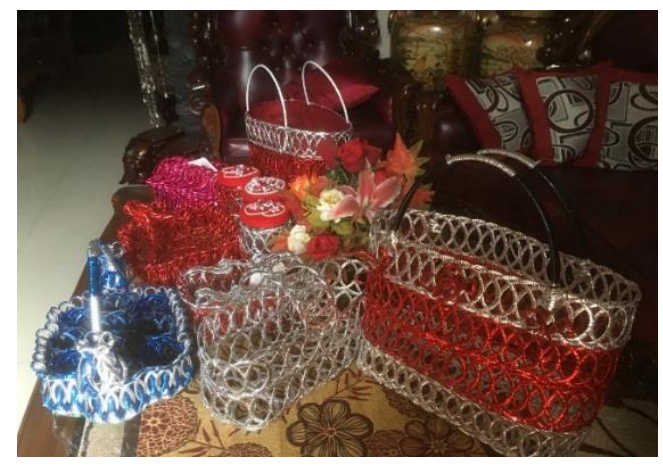

Gambar 4. Jenis-jenis produk yang dihasilkan

Adapun tingkat partisipasi peserta pelatihan dapat dilihat pada Tabel 1 .

Tabel 1. Tingkat partisipasi peserta pelatihan

\begin{tabular}{|c|c|c|}
\hline Variabel/Indikator & Skor $(\%)$ & Kategori \\
\hline \begin{tabular}{ll}
\multicolumn{2}{l}{ Tingkat Partisipasi } \\
- & Kehadiran \\
- & Keaktifan \\
- & Kesiapan \\
- & Inisiatif \\
- & kedisiplinan \\
\end{tabular} & $\begin{array}{l}89,90 \\
99,49 \\
76,67 \\
91,03 \\
86,92 \\
95,38 \\
\end{array}$ & $\begin{array}{c}\text { Sangat Tingg } \\
\text { Sangat Tingg } \\
\text { Tinggi } \\
\text { Sangat Tingg } \\
\text { Sangat Tingg } \\
\text { Sangat Tingg } \\
\end{array}$ \\
\hline
\end{tabular}

Sumber: Data telah diolah, 2019

Tabel 1 menunjukkan bahwa tingkat partisipasi peserta pelatihan pengolahan limbah plastik menjadi produk bernilai jual berada pada kategori sangat tinggi dilihat dari tingkat kehadiran, keaktifan, kesiapan, inisiatif, dan kedisiplinan. Ini berarti ibu-ibu rumah tangga dan remaja putri di Kecamatan Labakkang Kabupaten Pangkep memiliki partisipasi sangat tinggi dalam pelatihan pengolahan limbah plastik menjadi produk bernilai jual yang dapat dijadikan sebagai pekerjaan tambahan dalam menambah pendapatan keluarga.

Tingkat keterampilan yang dimiliki oleh peserta pelatihan setelah mengikuti pelatihan pengolahan limbah plastik menjadi produk bernilai jual dapat dilihat pada Tabel 2. 
Tabel 2. Tingkat keterampilan peserta pelatihan

\begin{tabular}{lcc}
\hline Variabel/Indikator & $\begin{array}{c}\text { Skor } \\
(\mathbf{\%})\end{array}$ & Kategori \\
\hline $\begin{array}{l}\text { Tingkat Keterampilan } \\
\text { - } \begin{array}{l}\text { Jumlah Jenis } \\
\text { produk yang } \\
\text { dihasilkan }\end{array}\end{array}$ & 78,29 & Terampil \\
- $\quad \begin{array}{l}\text { Kualitas Produk } \\
\text { Pemanfaatan }\end{array}$ & 87,18 & Beragam \\
$\begin{array}{l}\text { bahan baku } \\
\text { secara efektif }\end{array}$ & 74,62 & Berkualitas \\
\hline \multicolumn{2}{l}{ Sumber: Data telah diolah, 2019 } & \\
\hline
\end{tabular}

Tabel 2 menunjukkan tingkat keterampilan peserta pelatihan pengolah limbah plastik menjadi produk bernilai jual berada pada kategori terampil dilihat dari jumlah jenis produk yang dihasilkan beragam, produk yang dihasil berkualitas, dan pemanfaatan bahan baku secara efektif.

\section{KESIMPULAN}

Hasil pelaksanaan kemitraan masyarakat dapat ditarik kesimpulan:

1. Peserta pelatihan telah memiliki partisipasi sangat tinggi dalam pelatihan pengolahan sampah plastik menjadi produk bernilai jual dilihat dari kehadiran, keaktifan, kesiapan, inisiatif, dan kedisiplinan.

2. Peserta pelatihan terampil mengolah sampah plastik menjadi produk bernilai jual dilihat dari jumlah produk yang dihasilkan, kualitas produk, dan pemanfaatan bahan baku secara efektif.

\section{UCAPAN TERIMA KASIH}

Ucapan terima kasih disampaikan kepada Rektor Universitas Negeri Makassar yang telah memberikan dana PNBP dalam melaksanakan pengabdian ini. Selanjutnya ucapan terima kasih disampaikan pula kepada Ketua LP2M UNM dan Camat Labakkang beserta staf dan kepala desa/lurah se kecamatan Labakkang Kabupaten Pangkep yang telah memberi fasilitas dalam kegiatan PKM hingga selesai.

\section{DAFTAR PUSTAKA}

Afrina, M., \& Nurhamlin. (2014). Peran Ibu Rumah Tangga dalam Membantu Perekonomian Keluarga. Jurnal Online Mahasiswa (JOM) Bidang Ilmu Sosial dan Ilmu Politik, 1(1).

Anwar, M. Z. (2013). Organisasi Perempuan dan Pembangunan Kesejahteraan. Sosiologi Reflektif, 8(1), 133-146.

Attamimi, S. (2012). Membangun Keserasian Peran Ganda Ibu Rumah Tangga Muslimah dalam Era Masyarakat Ekonomi Modern. Musawa, 4(2), 199213.

Djabu, O., Goni, J. H., \& Tumiwa, J. (2013). Peranan Ibu Rumah Tangga yang Bekerja dalam Meningkatkan Status Sosial Keluarga di Kelurahan Teling Atas Kecamatan Wanea Kota Manado. Jurnal Acta Diurna, 2(3)

Marzuki, S. N. (2015). Peran Lembaga Pemberdayaan Masyarakat dalam Meningkatkan Pendapatan Ibu Rumah Tangga di Kecamatan Cina Kabupaten Bone Sulawesi Selatan. An-Nisa': Jurnal Studi Gender dan Islam, 7(1), 59-78. 